\title{
FAKTOR YANG MEMPENGARUHI BENDUNGAN ASI PADA IBU NIFAS
}

\author{
${ }^{1}$ Novalita Oriza \\ ${ }^{1}$ Institut Kesehatan Helvetia, Medan, Indonesia \\ email: novalitaoriza24@gmail.com
}

\author{
Artikel history \\ Dikirim, Februari $4^{\text {th }}, 2019$ \\ Ditinjau, Februari $17^{\text {th }}, 2019$ \\ Diterima, Juni $13^{\text {th }}, 2019$
}

\begin{abstract}
Background : The occurence of breastmilk inhibition is caused by uneasy milk supply, because the baby does not suckle enough on the mother often. The IDHS data in 2015 stated thae there are 35,985 of postpartum mother who experienced breastmilk inhobition or 15,6\% of postpartum mothers. Purpose : Determine the affecting factors on breastmilk inhibition in postpatum mothers at Working Area of Rambung Merah Health Center of Simalungun Regency in 2018. Methods : The research design is a qualitative analitycal survey with a cross-sectional approach. The populations in this study are 122 postpartum mothers. The sampling technique used an accidental sampling system as many as 92 respondents. The data analysis used univariate, bivariate ande multivariate with logistic regression test. Result : All independent variable affected breastmilk inhibitio with p-value <0.05. The result of logiztic regression test with the selection of the $p$-value model <0.25 was known to the variable that most influences the incidence of breastmilk inhibition was the frequency of breastfeeding with sig value $p=$ $0.000<0.25$ ande the largest $B$ (natural logarithm) value was 3.740. Conclusion : Breastfeeding frequency, nipple condition, breastfeeding attachment, breastfeeding position and breast careaffecting the occurence of breastmiilk inhibition in postpatum mothers at Working Area of Rambung Merah Health Center of Simalungun Regency in 2018 and the most variable affected breastmilk inhibition was breastfeeding frequency. Its expected that the Health Center officer will be more concerned and improve the information on lactation management and breast care.
\end{abstract}

Keywords : : Affecting Factors, Breastmilk Inhibition, Maternal Postpartum

Keywords: 3-5 kata atau gabungan kata, setiap kata dipisahkan dengan tanda titik koma (;)

\begin{abstract}
ABSTRAK
Pendahuluan : Kejadian Bendungan ASI yang disebabkan oleh pengeluaran air susu yang tidak lancar, karena bayi tidak cukup sering menyusu pada ibu nya. Data SDKI tahun2015 menyebutkan bahwa terdapat ibu nifas yang mengalami BendunganASI sebanyak 35.985 atau $(15,60 \%)$ ibu nifas. Tujuan : Untuk mengetahui faktor yang mempengaruhi bendungan ASI pada ibu nifas di Wilayah Kerja Puskesmas Rambung Merah Kabupaten Simalungun Tahun 2018.Metode : Desain penelitian adalah survei analitik kuantitatif dengan pendekatan cross sectional. Populasi dalam penelitian ini adalah 122 ibu nifas. Teknik pengambilan sampel menggunakan sistem accidental samplingsebanyak 92 responden. Analisis data menggunakan analisis univariat, bivariat dan multivariat dengan uji regresi logistik.Hasil : Seluruh variabel independen mempengaruhi bendungan ASI dengan nilai $p$-value $<0,05$. Hasil uji regresi logistik yang paling mempengaruhi kejadian bendungan ASI adalah frekuensi menyusui dengan nilai sig. $p=0,000<0,25$ dan nilai B (logaritma natural) terbesar yaitu 3,740.Kesimpulan : Faktor frekuensi menyusui, kondisi puting, perlekatan menyusui, posisi menyusui dan perawatan payudara memengaruhi kejadian bendungan ASI di wilayah kerja Puskesmas Rambung Merah Kabupaten Simalungun tahun 2018 dan variabel yang paling mempengaruhi kejadian bendungan ASI adalah frekeunsi menyusui. Diharapkan kepada petugas puskesmas agar lebih peduli dan meningkatkan informasi manajemen laktasi dan perawatan payudara.
\end{abstract}

Kata Kunci : Faktor yang Memengaruhi, Bendungan ASI, Ibu Nifas 


\section{PENDAHULUAN}

Seorang ibu yang baru melahirkan akan mengalami perubahan hidup karena kehadiran buah hatinya. Prioritas pertama saat itu adalah memberikan ASI sebagai makanan bagi bayinya.Pemberian Air Susu Ibu (ASI) bagi bayi baru lahir merupakan salah satu upayauntuk mencegah kematian dan masalah kekurangan gizi pada bayi dan balita.

ASI merupakan makanan yang paling sempurna bagi bayi, dimana kandungan gizi sesuai kebutuhan pertumbuhan dan perkembangan yang optimal.ASI mengandung zat untuk perkembangan kecerdasan, zat kekebalan (mencegah tubuh dari berbagai penyakit) dan dapat menjalani hubungan cinta kasih antara ibu dan bayi.Manfaat menyusui bagi ibu dapat mengurangi perdarahan setelah melahirkan, mempercepat pemulihan kecepatan ibu, seperti involusi rahim, menunda kehamilan, dan mengurangi resiko terkena kanker payudara.(1)

ASI yang tidak sering dikeluarkan dapat berkembang menjadi bendungan ASI, payudara terisi sangat penuh dengan ASI, aliran susu menjadi terhambat dan akan menyebabkan payudara bengkak. Selanjutnya jika bendungan ASI tidak segera tertangani akan mengakibatkan terjadinya tingkat keparahan yang berlanjut. ${ }^{(2)}$

\section{KejadianBendungan}

ASIyang

disebabkan oleh pengeluaran air susuyang tidak lancar, karena bayi tidak cukup sering menyusu pada ibu nya.Gangguan ini dapat menjadi lebih parah apabila ibu jarang menyusukanbayinya, akibatnya bayi tidak mendapatkan ASI secara Eksklusif dan apabilatidak segera di tangani maka akan menyebabkan Bendungan ASI padaPayudara, Pembendungan ASI dapat terjadi karena penyempitan duktuslakteferi atau oleh kelenjar-kelenjar tidak dikosongkan dengan sempurna ataukarena kelainan pada puting susu sehingga terjadinya pembengkakan padapayudara karena peningkatan aliran vena dan limfe sehingga menyebabkanbendungan ASI dan rasa nyeri disertai kenaikan suhu badan. (3)

Data World Health Orgnization(WHO) terbaru pada tahun 2015 di Amerika Serikatpersentase perempuan menyusui yang mengalami bendungan ASIrata-ratamencapai $87,05 \%$ atau sebanyak 8242 ibu nifas dari 12.765 orang, pada tahun2014 ibu yang mengalami bendungan ASI sebanyak 7198 orang dari 10.764orang dan pada tahun 2015 terdapat ibu yang mengalami bendungan ASIsebanyak 6543 orang dari 9.862 orang. (4)

DataAssociation of South East Asia

Nation(ASEAN) pada tahun 2013 menyimpulkan bahwa presentasecakupan kasus bendungan ASIpada ibu nifas tercatat 107.654 ibu nifas, padatahun 2014 terdapat ibu nifas yang mengalami bendungan ASI sebanyak95.698 orang, serta pada tahun 2015 ibu yang mengalami bendungan ASIsebanyak 76.543 orang. Hal ini disebabkan karena kesadaran masyarakatdalam mendorong peningkatan pemberian ASI masih relatif rendah. ${ }^{(4)}$

Menurut Data Survey Demografi dan Kesehatan Indonesia tahun2015 menyebutkan bahwa terdapat ibu nifas yang mengalami BendunganASI sebanyak 35.985 atau $(15,60 \%)$ ibu nifas, serta pada tahun 2015 ibunifas yang mengalami Bendungan ASI sebanyak 77.231 atau $(37,12 \%)$ ibu nifas. ${ }^{(5)}$

Peningkatan kejadian Bendungan ASIsangat berpengaruh terhadapmasa nifas karena ketidak berhasilan dalam memberikan ASI kepada bayinya. Salah satu tidak tercapainya ASI eksklusif yaitu bayi tidak mendapat ASIyang cukup serta produksi ASI meningkat, terlambat menyusukan,hubungan dengan bayi (bonding) kurang baik, dan dapat pula karenaadanya pembatasan waktu menyusui hingga dapat terjadinya peradanganpada payudara ibu dan secarapalpasi teraba keras, kadang terasa nyeriserta seringkali disertai peningkatan suhu badan ibu, dan terdapat tanda-tandakemerahan dan demam. ${ }^{(6)}$

Bendungan ASI terjadi karena beberapa faktor diantaranya yaitu teknik yang salah dalam menyusui, puting susu terbenam, bayi tidak dapat menghisap puting dan aerola, ibu yang tidak menyusukan bayinya sesering mungkin atau bayi yang tidak aktif menghisap. Diantara beberapa faktor penyebab diatas jika tidak segera ditangani akan berakibat ke mastitis.Pelekatan yang benar merupakan salah satu kunci keberhasilan bayi menyusu pada payudara ibu.Bila payudara lecet, bisa jadi petanda pelekatan bayi saat menyusu tidak baik. Umumnya, ibu akan memperbaiki posisi pelekatan dengan melepaskan mulut bayi saat menyusu dan menempelkannya kembali ${ }^{(7)}$

Bendungan ASI juga dapat terjadi dikarenakan faktor frekuensi pemberian ASI 
yang tidak teratur. Ardyan (2014)dalam penelitiannya mengatakan bahwa frekuensi dandurasi pemberian ASI mempunyai hubungan dengan terjadinya bendungan ASIpada Ibu nifas karena pada payudara terdapat vena limpatik yang mengalirkanproduksi air susu, jika frekuensi dan durasi pemberian ASI optimal, makapengosongan payudara dapat secara sempurna, aliran vena limpatik lancar,sehingga mencegah terjadinya payudara bengkak atau bendungan ASI padapayudara. ${ }^{(8)}$

Masalah dalam pemberian ASI salah satunya karena kurangnya informasi seperti ASI belum keluar pada hari pertama sehingga bayi dianggap perlu diberikan minuman lain, puting susu datar atau terbenam, puting susu lecet, dan payudara bengkak. ${ }^{(9)}$

Penelitian Halina (2015) mengatakan bahwateknik menyusui yang tidak benar dapat mengakibatkan puting susu menjadilecet dan ASI tidak keluar secara optimal sehingga mempengaruhi produksi ASIselanjutnya atau bayi enggan menyusu. Peneliti berasumsi dengan mencegahterjadinya puting lecet dapat mengurangi resiko terjadinya pembengakakanpada payudara, karena puting yang tidak lecet membuat ibu dan bayi maumenyusui dengan nyaman sehingga tidak menghambat pengeluaran ASI. ${ }^{(10)}$

Menurut Anggraeni (2015), posisi kepala bayiyang tidak benar bisa menyebabkan hisapan bayi yang salah, karena puting susudan areola yang tidak masuk semua kemulut bayi. Hal ini dapat mengakibatkanterjadinya puting lecet. Terjadinya puting lecet dapat menjadi resiko terjadinyapembengkakan pada payudara. Ibu post partum harus memastikan pelekatansudah tepat sehingga resiko terjadi pembengkakan pada payudara yaitu putinglecet tidak terjadi. ${ }^{(11)}$

Penelitian Yuliana (2012) mengatakan bahwa kejadian bendungan ASI disebabkankarena ibu mempunyai pengetahuan kurangtentang perawatan payudara, sehingga ibutidak benar dalam melakukan tindakanperawatan payudara dan waktu yang digunakan dalam melakukan perawatan payudara yang salah sehingga menyebabkan ibumengalami puting susu tenggelam, bayisusah menyusu, ASI tidak keluar,

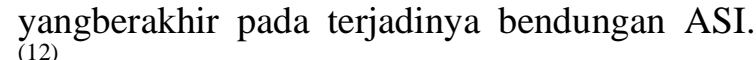

Perawatan payudara memiliki banyak manfaat antara lain: menjaga kebersihan payudara terutama kebersihan puting susu, melenturkan dan menguatkan puting susu sehingga memudahkan bayi untuk menyusu, merangsang kelenjar-kelenjar air susu sehingga produksi secara dini dan melakukan upaya untuk mengatasinya, mempersiapkan mental ibu untuk menyusui. Bila seorang ibu tidak melakukan perawatan payudara dengan benar maka sering dijumpai kasus-kasus yang akan merugikan ibu dan bayi, antara lain: ASI tidak keluar, puting susu tidak menonjol sehingga bayi sulit menghisap, produksi asi sedikit sehingga tidak cukup dikonsuksi bayi, infeksi pada payudara (payudara bengkak atau bernanah), muncul benjolan di payudara. ${ }^{(13)}$

Survei awal yang dilakukan pada bulan Juli 2018 di Puskesmas Rambung Merah Kabupaten Simalungun dengan mewawancarai 10 ibu postpartum yang menyusui bayinya pada minggu pertama setelah melahirkan terdapat6orang yang mengalami bendungan ASI.Dari hasil wawancara yang peneliti dapatkan,4 orang sudah mengetahui cara menyusui yang benar, 2 orang ibu mengatakan kondisi puting yang tenggelam ke dalam menjadi kendala proses menyusui, 2 orang ibu mengatakan sudah menghentikan menyusui karena payudaranya terasa sakitdan merasa tidak nyaman saat menyusui bayinya disebabkan karena cara pada saat menyusui yang tidak benar yaitu posisi duduk yang tidak tegak,kepala dan tubuh bayi tidak berada pada garis lurus dan dagu bayi tidak menyentuh payudara ibu dan 2 orang ibu tidak melakukan perawatan payudara dengan baik dan tidak melakukan perlekatan menyusui yang baik.

\section{METODE}

Desain penelitian ini adalah dilakukan secara survei analitik kuantitatif dengan pendekatan cross sectional, yang merupakan rancangan penelitian dimana variable bebas dan variable terikat diukur dan dikumpulkan dalam waktu yang bersamaan. Yang bertujuan untuk menentukan faktor yang mempengaruhibendungan ASI pada Ibu Nifas di Wilayah Kerja Puskesmas Rambung Merah Kabupaten Simalungun Tahun 2018.

Lokasi penelitian dilakukan di Wilayah Kerja Puskesmas Rambung Merah Kabupaten Simalungun Tahun 2018 dengan waktu penelitian ini dilaksanakan dari bulan Agustus hingga September 2018. 
Populasi adalah jumlah besar subjek yang mempunyai karakteristik tertentu, populasi dalam penelitian ini adalah seluruh ibunifas di Wilayah Kerja Puskesmas Rambung Merah Kabupaten Simalungun Tahun 2018 periode Agustus 2018 yang berjumlah 122 ibu nifas.Sampel adalah sebagian obyek yang diambil saat penelitian dari keseluruhan obyek yang diteliti dan dianggap mewakili populasi.(14)Teknik pengambilan sampel menggunakan sistem accidental sampling yaitu pengambilan sampel yang kebetulan ada atau tersedia sampai diperoleh sampel sebanyak 92 responden.

Metode pengumpulan data menggunakan data primer yang merupakan data karakteristik responden, frekuensi menyusui, kondisi puting, perlekatan menyusui, perilaku ibu, perawatan payudara dan kejadian bendungan ASI; data sekunder merupakan deskriptif di lokasi penelitian yaitu jumlah ibu nifas dan jumlah kejadian bendungan ASI; Data tertier adalah data riset yang sudah dipublikasikan secara resmi seperti jurnal, dan laporan penelitian(report).

Metode pengolahan datadalam penelitian ini menggunakan collecting, yaitu mengumpulkan data yang berasal dari kuesioner. Angket maupun observasi; checking, yang dilakukan dengan memeriksa kelengkapan jawaban kuesioner atau lembar observasi dengan tujuan agar data diolah secara benar sehingga pengolahan data memberikan hasil yang valid; coding, pada langkah ini penulis melakukan pemberian kode pada veriabel variabel yang diteliti misalnya nama responden dirubah menjadi nomor 1, 2, 3,....,42; Entering, yakni jawaban - jawaban dari masing - masing responden yang masih dalam bentuk "kode" (angka atau huruf ) dimasukkan kedalam aplikasi SPSS; dan data processing, yaitu semua data telah di input ke dalam aplikasi komputer akan diolah sesuai dengan kebutuhan dari penelitian. Serta analisa data dalam penelitian ini menggunakan analisa univariat dan bivariat menggunakan chisquare, dan analisa multivariat menggunakan regresi logistik.

\section{HASIL DAN PEMBAHASAN}

\section{Karakteristik}

Responden :Berdasarkan hasil penelitian dari tabel 1 didapati bahwa seluruh ibu nifas yang ada di wilayah kerja Puskesmas Rambung Merah Kabupaten Simalungun tahun 2018. Berdasarkan hasil pengumpulan data tentang karakteristik bahwa umur responden lebih banyak yang berumur $>21$ tahun sebanyak 49 orang $(53,3 \%)$ dan responden yang berumur $<22$ tahun sebanyak 43 orang $(46,7 \%)$. Berdasarkan hasil penelitian pada tingkat pendidikan responden yang berpendidikan Sekolah Dasar (SD) sebanyak 31 orang $(33,7 \%)$, SMP sebanyak 27 orang $(29,3 \%)$, SMA sebanyak 32 orang $(34,8 \%)$, dan Perguruan Tinggi (PT) sebanyak 2 orang $(2,2 \%)$.. Sedangkan berdasarkan hasil penelitian pada kategori pekerjaan responden diketahui lebih banyak respondenbekerja sebanyak 55 orang $(59,8 \%)$ dan responden yang tidak bekerja sebanyak 37 orang $(40,2 \%)$.

Tabel 1. Karakteristik Responden

\begin{tabular}{lccc}
\hline & Karakteristik & f & \% \\
\cline { 1 - 2 } Umur & 43 & 46,7 \\
$>22$ tahun & 49 & 53,3 \\
\hline Pendidikan & & \\
\hline SD & 31 & 33,7 \\
SMP & 27 & 29,3 \\
SMA & 32 & 34,8 \\
PT & 2 & 2,2 \\
\hline Pekerjaan & & \\
\hline Bekerja & 55 & 59,8 \\
Tidak Bekerja & 37 & 40,2 \\
\hline
\end{tabular}

Analisa Univariat :Berdasarkan hasil penelitian pada tabel 2 didapati hasil bahwa dari92 orang diketahui respondenyang frekuensi menyusui baik sebanyak 26 orang $(28,3 \%)$, 
frekuensi menyusui kurang sebanyak 66 orang $(71,7 \%)$. Dari 92 orang diketahui respondenyang memiliki kondisi putingbaik sebanyak 54 orang $(58,7 \%)$ dan responden yang memiliki kondisi putingkurang sebanyak 38 orang $(57,3 \%)$. Dari 92 orang diketahui responden yang melakukan perlekatan menyusui baik sebanyak 43 orang $(46,7 \%)$ dan responden yang melakukan perlekatan menyusui kurang sebanyak 49 orang $(53,3 \%)$.Dari 92 orang diketahui responden yang melakukan posisi menyusui dengan baik sebanyak 30 orang $(32,6 \%)$ dan responden yang melakukan posisi menyusui kurang sebanyak 62 orang $(67,4 \%)$. Dari 92 orang diketahui responden yang melakukan perawatan baik sebanyak 61 orang $(66,3 \%)$ dan responden yang melakukan perawatan payudara kurang sebanyak 31 orang $(33,7 \%)$. Dari 92 orang diketahui responden yang mengalami terjadinya bendungan ASI sebanyak 27 orang $(29,3 \%)$ dan responden yang tidak terjadi bendungan ASI sebanyak 65 orang $(70,7 \%)$.

Tabel 2. Analisa Univariat

\begin{tabular}{lcc}
\hline \multicolumn{1}{c}{ Variabel } & f & $\%$ \\
\cline { 1 - 2 } Frekuensi Menyusui & 26 & 28,3 \\
Baik & 66 & 71,7 \\
\hline Kondisi Puting & 54 & 58,7 \\
\hline Baik & 38 & 41,3 \\
Kurang & & \\
\hline Perlekatan Menyusui & 43 & 46,7 \\
\hline Baik & 49 & 53,3 \\
\hline Kurang & & 32,6 \\
\hline Posisi Menyusui & 30 & 67,4 \\
Kuik & 62 & 66,3 \\
\hline Perawatan Payudara & & 33,7 \\
\hline Baik & 61 & 29,3 \\
Kurang & 31 & 70,7 \\
\hline Bendungan ASI & & \\
\hline Baik & 27 & \\
Kurang & 65 & \\
\hline
\end{tabular}

Analisa Bivariat : Berdasarkan tabel 3 dapat didapati hasil bahwa dari 26 orang yang frekuensi menyusuinya baik 20 orang (76,9\%) mengalami terjadinya bendungan ASI dan 6 orang tidak mengalami. Dari 66 orang yang frekuensi menyusuinya kurang 7 orang $(10,6 \%)$ mengalami terjadinya bendungan ASI dan 59 orang $(89,4 \%)$ tidak mengalami.Hasil uji statistik diperoleh nilai $p=0,000$ yang artinya ada hubungan frekuensi menyusui dengan kejadian bendungan $\mathrm{ASi}$ di wilayah kerja Puskesmas Rambung Merah Kabupaten Simalungun Tahun 2018.

Dari 54 orang yang kondisi putingnya baik 10 orang $(18,5 \%)$ mengalami terjadinya bendungan ASI dan 44 orang tidak mengalami. Dari 38 orang yang kondisi putingnya kurang 17 orang $(44,7 \%)$ mengalami terjadinya bendungan ASI dan 21 orang (55,3\%) tidak mengalami. Hasil uji statistik diperoleh nilai $p=$ 0,007 yang artinya ada hubungan kondisi puting dengan kejadian bendungan ASi di wilayah kerja Puskesmas Rambung Merah Kabupaten Simalungun Tahun 2018.

Dari dari 43 orang yang perlekatan menyusui baik 19 orang $(44,2 \%)$ mengalami terjadinya bendungan ASI dan 24 orang tidak mengalami. Dari 49 orang yang perlekatan menyusui kurang 8 orang $(16,3 \%)$ mengalami terjadinya bendungan ASI dan 41 orang $(83,7 \%)$ tidak mengalami. Hasil uji statistik diperoleh nilai $p=0,003$ yang artinya ada hubungan perlekatan menyusui dengan kejadian bendungan ASi di wilayah kerja Puskesmas Rambung Merah Kabupaten Simalungun Tahun 2018. 
Dari 30 orang yang posisi menyusui baik 19 orang $(63,3 \%)$ mengalami terjadinya bendungan ASI dan 11 orang tidak mengalami. Dari 62 orang yang posisi menyusui kurang 8 orang $(12,9 \%)$ mengalami terjadinya bendungan ASI dan 54 orang $(87,1 \%)$ tidak mengalami.Hasil uji statistik diperoleh nilai $p=$ 0,000 yang artinya ada hubungan posisi menyusui dengan kejadian bendungan ASi di wilayah kerja Puskesmas Rambung Merah Kabupaten Simalungun Tahun 2018.
Dari 61 orang yang perawatan payudara baik 12 orang $(19,7 \%)$ mengalami terjadinya bendungan ASI dan 49 orang tidak mengalami. Dari 31 orang yang perawatan payudara kurang 15 orang $(48,4 \%)$ mengalami terjadinya bendungan ASI dan 16 orang $(51,6 \%)$ tidak mengalami.Hasil uji statistik diperoleh nilai $p=$ 0,005 yang artinya ada hubungan perawatan payudara dengan kejadian bendungan ASI di wilayah kerja Puskesmas Rambung Merah Kabupaten Simalungun Tahun 2018.

Tabel 3.Analisa Bivariat

\begin{tabular}{|c|c|c|c|c|c|c|c|}
\hline \multirow{3}{*}{ Variabel } & \multicolumn{4}{|c|}{ Bendungan ASI } & \multirow{3}{*}{ Total } & \multirow{3}{*}{$\%$} & \multirow{3}{*}{ Sig- $p$} \\
\hline & \multicolumn{2}{|c|}{ Terjadi } & \multicolumn{2}{|c|}{ Tidak Terjadi } & & & \\
\hline & f & $\%$ & $\mathbf{f}$ & $\%$ & & & \\
\hline \multicolumn{8}{|l|}{ Frekuensi Menyusui } \\
\hline Baik & 20 & 76,9 & 6 & 23,1 & 26 & 100 & \multirow{2}{*}{0,000} \\
\hline Kurang & 7 & 10,6 & 59 & 89,4 & 66 & 100 & \\
\hline \multicolumn{8}{|l|}{ Kondisi Puting } \\
\hline Baik & 10 & 18,5 & 44 & 81,5 & 54 & 100 & \multirow{2}{*}{0,007} \\
\hline Kurang & 17 & 44,7 & 21 & 55,3 & 38 & 100 & \\
\hline \multicolumn{8}{|l|}{ Perlekatan Menyusui } \\
\hline Baik & 19 & 44,2 & 24 & 55,8 & 43 & 100 & \multirow{2}{*}{0,003} \\
\hline Kurang & 8 & 16,3 & 41 & 83,7 & 49 & 100 & \\
\hline \multicolumn{8}{|l|}{ Posisi Menyusui } \\
\hline Baik & 19 & 63,3 & 11 & 36,7 & 30 & 100 & \multirow{2}{*}{0,007} \\
\hline Kurang & 8 & 12,9 & 54 & 87,1 & 62 & 100 & \\
\hline \multicolumn{8}{|l|}{ Perawatan Payudara } \\
\hline Baik & 12 & 19,7 & 49 & 80,3 & 61 & 100 & \multirow{2}{*}{0,005} \\
\hline Kurang & 15 & 48,4 & 16 & 51,6 & 31 & 100 & \\
\hline
\end{tabular}

Analisa Multivatiat Tahap I :Hasil analisis dari tabel 4 dapat diketahui bahwa nilai p-value terbesar dan $>0,05$ adalah variabel perawatan payudara, perlekatan menyusui dan kondisi puting, sehingga harus dikeluarkan dari model untuk multivariat.

Tabel 4. Analisa Multivariat Tahap I

Variables in the Equation

\begin{tabular}{llrrrrrr}
\hline & & \multicolumn{1}{c}{ B } & \multicolumn{1}{c}{ S.E. } & \multicolumn{1}{c}{ Wald } & df & \multicolumn{1}{c}{ Sig. } & \multicolumn{1}{c}{$\operatorname{Exp}(\mathbf{B})$} \\
\hline Step 1 $^{\text {a }}$ & Frek & 4.091 & .953 & 18.423 & 1 & .000 & 59.827 \\
& Kondisi & -1.520 & .882 & 2.971 & 1 & .085 & .219 \\
& Lekat & .993 & .851 & 1.360 & 1 & .243 & 2.699 \\
& Posisi & 3.106 & .888 & 12.235 & 1 & .000 & 22.334 \\
& Rawat & -.170 & .900 & .036 & 1 & .850 & .844 \\
& Constant & -9.945 & 3.288 & 9.145 & 1 & .002 & .000 \\
\hline
\end{tabular}

a. Variable(s) entered on step 1: Frek, Kondisi, Lekat, Posisi, Rawat.

Analisa Multivariat Tahap II :Berdasarkan hasil di atas diketahui bahwa terdapat 2 variabel bebas yang signifikan berpengaruh terhadap kejadian bendungan ASI karena masing-masing variabel tersebut memiliki nilai signifikansi $p<0,25$. Variabel- 
variabel tersebut adalah variabel frekuensi menyusui dengan nilai Sig. $=0,000$ dan variabel posisi menyusuidengan nilai Sig. $=0,000$. Variabel yang paling dominan memengaruhi kejadian bendungan ASI dari 2 variabel yang memiliki nilai sig $p<0,25$ adalah variabel frekuensi menyusui dengan nilai $\mathrm{B}$ atau logaritma natural terbesar yaitu 3,740 .

Besarnya pengaruh ditunjukkan dengan nilai EXP (B) atau OR. Besar OR dalam penelitian ini yaitu 1) Variabel frekuensi menyusui memiliki nilai OR sebesar 42,097, maka responden dengan frekuensi menyusui dalam kategori tinggi memiliki kecenderungan tidak mengalami kejadian bendungan ASI sebesar 42,097. Nilai B atau logaritma natural dari 42,097 adalah 3,740. Oleh karena nilai B bernilai positif, maka variabel frekuensi menyusui memiliki hubungan positif dengan kejadian bendungan ASI atau semakin sering frekuensi menyusui maka kejadian bendungan ASI cenderung tidak terjadi; 2) Variabel posisi menyusui memiliki nilai OR sebesar 18,555, maka responden dengan posisi menyusui dalam kategori tinggi memiliki kecenderungan tidak mengalami kejadian bendungan ASI sebesar 18,555. Nilai B atau logaritma natural dari 18,555 adalah 2,921.Oleh karena nilai B bernilai positif, maka variabel posisi menyusui memiliki hubungan positif dengan kejadian bendungan ASI atau semakin baik posisi menyusui maka kejadian bendungan ASI cenderung tidak terjadi.

Tabel 5. Analisa Multivariat Tahap II

Variables in the Equation

\begin{tabular}{|c|c|c|c|c|c|c|c|}
\hline & & $\mathrm{B}$ & S.E. & Wald & df & Sig. & $\operatorname{Exp}(B)$ \\
\hline \multirow[t]{3}{*}{ Step $1^{\mathrm{a}}$} & Frek & 3.740 & .837 & 19.967 & 1 & .000 & 42.097 \\
\hline & Posisi & 2.921 & .825 & 12.545 & 1 & .000 & 18.555 \\
\hline & Constant & -10.202 & 2.158 & 22.349 & 1 & .000 & .000 \\
\hline
\end{tabular}

Variable(s) entered on step 1: Frek, Posisi.

\section{PEMBAHASAN}

\section{Pengaruh Frekuensi Menyusui terhadap Bendungan ASI}

Hasil penelitian analisis univariat tentang frekuensi menyusui mayoritas dalam kategori kurang $(89,4 \%)$. Hasil uji chi square diperoleh nilai $p=0,000$ yang artinya ada hubungan frekuensi menyusui dengan kejadian bendungan ASI di wilayah kerja Puskesmas Rambung Merah Kabupaten Simalungun Tahun 2018. Dari hasil multivariat dengan uji regresi logistik, variabel frekuensi menyusui secara signifikan memengaruhi responden terhadap kejadian bendungan ASI dengan nilai sig. = 0,000 .

Hasil penelitian ini sesuai yang dikatakan Maryandhini (2014) yang mengatakan bahwa hampir seluruh ibu nifas yang frekuensi menyusui baik tidak terjadi bendungan ASI (87,5\%). Hasil uji statistik, dengan tingkat kesalahan $\alpha=0,05$ dan $\mathrm{df}=1$, didapatkan $\mathrm{X}^{2}$ hitung $(8,99)>\mathrm{X}^{2}$ tabel $(3,841)$ maka $\mathrm{H}_{0}$ ditolak, artinya ada hubungan antara

Seorang ibu dapat memiliki kapasitas penyimpanan yang memungkinkan payudara frekuensi menyusui dengan kejadian bendungan ASI.(15)

Penelitian ini sejalan dengan penelitian Ardyan (2014) mengenai Bendungan ASI juga dapat terjadi dikarenakan faktor frekuensi pemberian ASI yang tidak teratur dalam penelitiannya mengatakan bahwa frekuensi dandurasi pemberian ASI mempunyai hubungan dengan terjadinya bendungan ASIpada Ibu nifas karena pada payudara terdapat vena limpatik yang mengalirkanproduksi air susu, jika frekuensi dan durasi pemberian ASI optimal, makapengosongan payudara dapat secara sempurna, aliran vena limpatik lancar,sehingga mencegah terjadinya payudara bengkak atau bendungan ASI padapayudara. (8)

Menurut Cadwell (2011), terdapat beberapa faktor yang berperan dalam menentukan kisaran frekuensi pemberian ASI untuk bayi yang sedang menyusui. Ibu memiliki kapasitas jumlah penyimpanan ASI yang berbeda dalam payudara mereka.Kapasitas penyimpanan ASI ini adalah jumlah ASI yang dapat terakumulasi sebelum memberikan sel-sel suatu pesan untuk mengurangi jumlah ASI. menyimpan ASI lebih lama atau lebih singkat dibandingkan dengan ibu yang lain.(16) 
Menurut asumsi peneliti bahwa ibu post partum harus memastikan pelekatan sudah tepat sehingga resiko terjadi pembengkakan pada payudara yaitu puting lecet tidak terjadi. Perlekatan menyusui akan memberi rasa nyaman kepada bayi dalam proses menyusui sehingga bayi akan menyusu dengan baik. Berdasarkan perekatan menyusui yang baik bahwa yang tidak terjadi Bendungan ASI disebabkan oleh posisi mulut bayi ketika menyusu menempel dengan baik sehingga bayi menelan ASI dengan mudah dan jumlah yang cukup, dan pada akhirnya akan meningkatkan produksi ASI sesuai kebutuhan bayi,namun dalam penelitian ini ibu yang perlekatan menyusui baik terjadi Bendungan ASI dikarenakan oleh kondisi puting yang kurang baik sehingga mempengaruhi proses menyusui bayi. Berdasarkan perlekatan menyusui yang kurang bahwa yang terjadi Bendungan ASI disebabkan oleh perlekatan yang tidak benar sehingga terjadi pergesekan puting susu dengan langit-langit mulut bayi, namun dalam penelitian ini ibu yang perlekatan menyusui yang kurang tidak terjadi Bendungan ASI disebabkan oleh ibu yang melakukan perawatan payudara yang baik sehingga terhindar dari puting lecet.

\section{PengaruhKondisi Puting terhadap Bendungan ASI}

Hasil penelitian analisis univariat tentang kondisi puting mayoritas dalam kategori baik $(81,5 \%)$. Hasil uji chi square diperoleh nilai $p=0,007$ yang artinya ada hubungan kondisi puting dengan kejadian bendungan ASi di wilayah kerja Puskesmas Rambung Merah Kabupaten Simalungun Tahun 2018. Dari hasil multivariat dengan uji regresi logistik, variabel kondisi puting secara signifikan tidak memengaruhi responden terhadap kejadian bendungan ASI dengan nilai sig. $=0,085$.

Hasil penelitian ini sesuai yang dikatakan Anggraeni (11)dengan hasil uji chisquare didapatkan bahwa ada hubungan antara kondisi puting susu dengan terjadinya pembengkakan payudara di Rumah Sakit Pondok Indah (P value $=0,000 ; \alpha=0,05)$.

Penelitian ini selaras dengan penelitian yang dilakukan oleh Eny (2010), dalam penelitian Halina (2015) mengatakan bahwa teknik menyusui yang tidak benar dapat mengakibatkan puting susu menjadi lecet dan ASI tidak keluar secara optimal sehingga mempengaruhi produksi ASI selanjutnya atau bayi enggan menyusu. Peneliti berasumsi dengan mencegah terjadinya puting lecet dapat mengurangi resiko terjadinya pembengakakan pada payudara, karena puting yang tidak lecet membuat ibu dan bayi mau menyusui dengan nyaman sehingga tidak menghambat pengeluaran ASI.(10)

Penelitian ini sejalan dengan penelitian Amelia mengenai Faktor-Faktor yang Memengaruhi Kejadian Bendungan ASI pada Ibu Postpartum di RSIA Siti Fatimah Makassar didapati hasil bahwa ibu postpartum yang tidak menyusui secara on-demand sebanyak $66,67 \%$, penderita bendungan ASI tidak ditemukan pada ibu postpartum dengan posisi menyusui yang tidak benar sebanyak 88,89\%, penderita bendungan ASI tidak ditemukan pada ibu postpartum yang mempunyai kelainan putting susu sebanyak $77,78 \%$. Kesimpulannya yaitu bahwa sebagian besar ibu postpartum yang mengalami bendungan ASI dipengaruhi oleh faktor tidak menyusui secara on-demand dan kelainan putting susu cukup berpengaruh terhadap kejadian bendungan ASI. (17)

Menurut Farrer (2011), kesulitan yang timbul selama proses laktasi yaitu puting yang retak-retak, puting yang masuk ke dalam, mastitis infektif dan laktasi yang tidak memadahi oleh karena banyak sekali masalah yang timbul selama proses menyusui, maka perlu dilakukan perawatan antenatal yang baik karena ASI berperan penting untuk membuat bayi sehat dan kuat.(18)

Menurut asumsi peneliti bahwa dapat dinyatakan kondisi puting adalah salah satu faktor kejadian bendungan ASI pada ibu nifas.Semakin baik kondisi puting ibu akan mencegah terjadinya bendungan ASI. Berdasarkan Kondisi Puting yang baik bahwa yang tidak terjadi Bendungan ASI disebabkan oleh ibu yang menyusui dengan benar sehingga tidak terjadi puting lecet, namun dalam penelitian ini ibu yang kondisi puting baik terjadi Bendungan ASI dikarenakan oleh ibu yang merasakan perih ketika menyusui menghentikan proses menyusui dan menggantinya dengan susu formula. Berdasarkan Kondisi Puting yang kurang bahwa yang terjadi Bendungan ASI disebabkan oleh posisi menyusui yang salah sehingga menyebabkan puting lecet, namun dalam penelitian ini ibu yang Kondisi Puting yang kurang tidak terjadi Bendungan ASI disebabkan oleh ibu yang menyusui dengan 
posisi mulut bayi dan puting susu benar sehingga dapat mengurangi rasa perih dan ASI dapat keluar lancar.

\section{PengaruhPerlekatan Menyusui terhadap Bendungan ASI}

Hasil penelitian analisis univariat tentang perlekatan menyusui mayoritas dalam kategori kurang $(53,3 \%)$. Hasil uji chi square diperoleh nilai $p=0,003$ yang artinya ada hubungan perlakatan dengan kejadian bendungan ASI di wilayah kerja Puskesmas Rambung Merah Kabupaten Simalungun Tahun 2018. Dari hasil multivariat dengan uji regresi logistik, variabel perlekatan menyusui secara signifikan tidak memengaruhi responden terhadap kejadian bendungan ASI dengan nilai sig. $=0,243$.

Hasil penelitian ini sesuai yang dikatakan Anggraeni dengan hasil uji chi square didapatkan bahwa ada hubungan antara perlekatan menyusui dengan terjadinya pembengkakan payudara di Rumah Sakit Pondok Indah (P value $=0,000 ; \alpha=0,05)$.(11)

Hasil penelitian sesuai dengan Astutik (2015), menyusui dengan teknik yang tidak benar dapat menyebabkan putting susu lecet dan ASI tidak keluar secara optimal sehingga mempengaruhi produksi ASI selanjutnya atau bayi enggan menyusu, $42.9 \%$ responden mengatakan ketika menyusui dahi bayi tidak menempel pada payudara ibu seharusnya dahi bayi menempel pada payudara ibu karena jika dahi bayi tidak menempel pada payudara ibu maka bayi hanya dapat menghisap sebagian puting saja.(19)

Penelitian ini juga sejalan dengan penelitian Iin dan Titik mengenai Analisa Hubungan Pengaruh Cara Menyusui dengan Kejadian Payudara Bengkak pada Ibu Post Partum yang didapati hasil berdasarkan uji Chi Square dengan level signifikan 0,05 pada hubungan cara menyusui yang benar dengan kejadian payudara bengkak diperoleh hasil perhitungan $\mathrm{X} 2=17,45(\mathrm{P}=0,000)$. dari hasil uji statistik tersebut didapatkan $\mathrm{p}<\dot{\alpha}$, artinya ada hubungan cara menyusui yang benar dengan kejadian payudara bengkak.(20)

Menurut Sulityawati (2014), untuk mendapatkan perlekatan yang maksimal, penting untuk memberikan topangan atau

Tahun 2018. Dari hasil multivariat dengan uji regresi logistik, variabel posisi sandaran pada punggung ibu dalam posisi tegak lurus terhadap pangkuannya. Ini mungkin dapat dilakukan dengan duduk bersila diatas tempat tidur, dilantai atau dikursi. Dengan posisi miring atau duduk (punggung dan kaki ditopang), akan membantu bentuk payudaranya dan memberikan ruang untuk menggerakkan bayinya ke posisi yang baik. Badan bayi harus dihadapkan ke arah badan ibu dan mulutnya berada dihadapan puting susu ibu. Leher bayi harus sedikit ditengadahkan. Bayi sebaiknya ditopang pada bahunya sehingga posisi kepala dapat dipertahankan untuk agak tengadah.(2)

Menurut asumsi peneliti bahwa ibu post partum harus memastikan pelekatan sudah tepat sehingga resiko terjadi pembengkakan pada payudara yaitu puting lecet tidak terjadi. Perlekatan menyusui akan memberi rasa nyaman kepada bayi dalam proses menyusui sehingga bayi akan menyusu dengan baik. Berdasarkan perekatan menyusui yang baik bahwa yang tidak terjadi Bendungan ASI disebabkan oleh posisi mulut bayi ketika menyusu menempel dengan baik sehingga bayi menelan ASI dengan mudah dan jumlah yang cukup, dan pada akhirnya akan meningkatkan produksi ASI sesuai kebutuhan bayi,namun dalam penelitian ini ibu yang perlekatan menyusui baik terjadi Bendungan ASI dikarenakan oleh kondisi puting yang kurang baik sehingga mempengaruhi proses menyusui bayi. Berdasarkan perlekatan menyusui yang kurang bahwa yang terjadi Bendungan ASI disebabkan oleh perlekatan yang tidak benar sehingga terjadi pergesekan puting susu dengan langit-langit mulut bayi, namun dalam penelitian ini ibu yang perlekatan menyusui yang kurang tidak terjadi Bendungan ASI disebabkan oleh ibu yang melakukan perawatan payudara yang baik sehingga terhindar dari puting lecet.

\section{PengaruhPosisi Menyusui terhadap Bendungan ASI}

Hasil penelitian analisis univariat tentang posisi menyusui mayoritas dalam kategori kurang $(67,4 \%)$. Hasil uji chi square diperoleh nilai $p=0,007$ yang artinya ada hubungan posisi menyusui dengan kejadian bendungan ASI di wilayah kerja Puskesmas Rambung Merah Kabupaten Simalungun 
menyusui secara signifikan memengaruhi responden terhadap kejadian bendungan ASI dengan nilai sig. $=0,000$.

Hasil penelitian ini sesuai yang dikatakan Anggraeni dengan hasil uji chi square didapatkan bahwa ada hubungan antara posisi menyusui dengan terjadinya pembengkakan payudara di Rumah Sakit Pondok Indah (P value $=0,000 ; \alpha=0,05)$. (39) Hasil penelitian ini selaras dengan penelitian yang dilakukan oleh Aeni (2014), didapatkan data bahwa pada responden dengan cara menyusui kurang baik dan mengalami bendungan ASI $(53,3 \%)$ dan pada responden dengan cara menyusui baik dan mengalami bendungan ASI $(10,7 \%) .(21)$

Penelitian ini tidak sejalan dengan penelitian Amelia mengenai Faktor-Faktor yang Memengaruhi Kejadian Bendungan ASI pada Ibu Postpartum di RSIA Siti Fatimah Makassar didapati hasil bahwa ibu postpartum yang tidak menyusui secara on-demand sebanyak $66,67 \%$, penderita bendungan ASI tidak ditemukan pada ibu postpartum dengan posisi menyusui yang tidak benar sebanyak $88,89 \%$, penderita bendungan ASI tidak ditemukan pada ibu postpartum yang mempunyai kelainan putting susu sebanyak 77,78\%. (17)

Menurut Sulityawati (2014), Menurut Sulistiawati, Ari, bila di posisikan dengan benar, bayi akan membentuk suatu pentil, jaringan putting susu, dan payudara, serta sinus lactiferous sekarang akan berada dalam rongga mulut bayi. Putting susu akan masuk sampai sejauh langit-langit lunak (velum platinum) dan bersentuhan dengan langit-langit tersebut. Sentuhan ini akan merangsang reflex penghisapan. Rahang bawah bayi menutup pada jaringan payudara, penghisapan akan terjadi, dan putting susu ditangkap dengan baik dalam rongga mulut, sementara lidah memberikan penekanan yang berulang-ulang secara teratur sehingga ASI akan keluar dari duktus lactiferous.(2)

Menurut asumsi peneliti bahwa posisi menyusui yang kurang tepat dapat menyebabkan pembengkakan payudara.Berdasarkan posisi menyusui yang baik bahwa yang tidak terjadi Bendungan ASI disebabkan oleh posisi menyusui ibuyang sudah tepat sehingga bayi dapat menghisap puting susu dengan nyaman dan tidak tertekan,namun dalam penelitian ini ibu yang posisi menyusui baik terjadi Bendungan ASI dikarenakan olehkarena latar belakang pekerjaan ibu yang terlalu sibuk mengurusi pekerjaan rumah sehingga kurang merawat payudara yang menyebabkan kondisi payudara yang tidak baik. Berdasarkan posisi menyusui yang kurang bahwa yang terjadi Bendungan ASI disebabkan olehkarena posisi menyusui kurang tepat seingga membuat ibu dan bayi merasa tidak nyaman saat menyusu dan dapat membuat puting ibu lecet, namun dalam penelitian ini ibu yang posisi menyusui yang kurang tidak terjadi Bendungan ASI disebabkan oleh latar belakang ibu yang berpendidikan tinggi sehingga walaupun tidak dapat menyusui dengan baik tetapi masih dapat melakukan cara lain seperti memompa ASI sehingga produksi ASI dapat lancar dengan rangsangan dari proses memompa ASI tersebut.

\section{PengaruhPerawatan Payudara terhadap Bendungan ASI}

Hasil penelitian analisis univariat tentang perawatan payudara mayoritas dalam kategori baik (66,3\%). Hasil uji chi square diperoleh nilai $p=0,005$ yang artinya ada hubungan perawatan payudara dengan kejadian bendungan ASI di wilayah kerja Puskesmas Rambung Merah Kabupaten Simalungun Tahun 2018. Dari hasil multivariat dengan uji regresi logistik, variabel perawatan payudara secara signifikan tidak memengaruhi responden terhadap kejadian bendungan ASI dengan nilai sig. $=0,850$.

Hasil penelitian ini sesuai yang dikatakan Estu dengan Hasil uji statistik Chi square untuk mengetahui hubungan antara breast care dengan kejadian bendungan ASI diperoleh nilai $\mathrm{X} 2=11,327$ dengan pvalue $=$ $0,003$ ( $\mathrm{p}<0,05)$ yang berarti ada hubungan antara breast care dengan kejadian bendungan ASI di BidanPraktek Swasta (BPS) wilayah kerja Puskesmas Wuryantoro Wonogiri.(22)

Penelitian ini juga sejalan dengan penelitian Evi Rosita (2016) mengenai Hubungan Perawatan pada Ibu Nifas dengan Bendungan ASI didapati hasil bahwa $\rho$ value $0,001<$ nilai $\alpha 0,05(0,001<0,05)$, sehingga $\mathrm{H} 1$ diterima. Kesimpulan dari penelitian ini adalah ada hubungan antara perawatan payudara pada ibu nifas dengan bendungan ASI di Desa Jolotundo dan Kupang Kecamatan Jetis Kabupaten Mojokerto Tahun 2016.(23)

Penelitian ini juga sejalan dengan penelitian Nur Scholichah mengenai Hubungan Perawatan Payudara Pada Ibu Postpartum dengan Pengeluaran ASI di Desa Karang Duren 
Kecamatan Tengaran Kabupaten Semarang dengan hasil sebagian besar responden $(51,6 \%)$

pada masa nifas yang kurang baik. Ibu post partum di Desa Karangduren Kecamatan Tengaran Kabupaten Semarang sebagian besar $(51,6 \%)$ mempunyai kelancaran pengeluaran ASI yang lancar. Ada hubungan antara perawatan payudara pada ibu post partum dengan kelancaran pengeluaran ASI di Desa Karangduren Kecamatan Tengaran Kabupaten Semarang dengan $p=0,007 .(24)$

Merupakan suatu tindakan perawatan payudara yang dilaksanakan, baik oleh pasien maupun dibantu orang lain yang dilaksanakn mulai hari pertama ataukedua setelah melahirkan. Perawatan payudara bertujuan untuk melancarkan sirkulasi darah dan mencegah tersumbatnya aliran susu sehingga memperlancar pengeluaran ASI, serta menghindari terjadinya pembekakan dan kesulitan menyusui, selain itu juga menjaga kebersihan payudara agar tidak mudah terkena infeksi.(25)

Menurut asumsi peneliti bahwa gerakan pada perawatan payudara bermanfaat melancarkan reflek pengeluaran ASI. Berdasarkan perawatan payudara yang baik bahwa yang tidak terjadi Bendungan ASI disebabkan oleh ibu yang rutin melakukan perawatan payudara seperti membersihkan puting dengan air hangat setiap habis mandi untuk menjaga kebersihannya dan menghindari penggunaan sabun yang bisa membuat bagian puting kering' namun dalam penelitian ini ibu yang perawatan payudara baik terjadi Bendungan ASI dikarenakan oleh latar belakang faktor ekonomi yang tidak memunginkan ibu untuk memenuhi kebutuhan nutrisi dan gizi selama masa nifas sehingga produksi ASI terganggu. Berdasarkan perawatan payudara yang kurang bahwa yang terjadi Bendungan ASI disebabkan oleh kurang perawatannya payudara sehingga membuat payudara kering menyebabkan lapisan puting mengelupas dan muncul rasa sakit ketika menyusui, namun dalam penelitian ini ibu yang perawatan payudara yang kurang tidak terjadi Bendungan ASI disebabkan oleh latar belakang pekerjaan ibu yang mayoritas adalah ibu rumah tangga sehingga walaupun payudara ibu kurang terawat namun ibu memiliki banyak waktu untuk menyusui bayinya sehingga dengan frekuensi menyusui yang baik akan merangsang produksi mempunyai

perawatan

payudara

ASI menjadi lancar dan terhindar dari kejadian bendungan ASI.

\section{PengaruhFrekuensi Menyusui, Kondisi Puting, Perlekatan Payudara, Posisi Menyusui danPerawatan Payudara terhadap Bendungan ASI}

Berdasarkan hasil penelitian yang telah dilakukan di Puskesmas Rambung Merah Kabupaten Simalungun Tahun 2018, dengan menggunakan analisis regresi logistik diketahui nilai R. Square sebesar 0,721 atau $72 \%$. Hal ini berarti, variabilitas variabel independen dapat dijelaskan oleh variabel-variabel independen sebesar $72 \%$. Artinya, seluruh variabel independen memengaruhi variabel dependen secara serentak pada kisaran $72 \%$, sedangkan $28 \%$ lainnya dipengaruhi atau dijelaskan oleh variabel-variabel yang tidak dimasukkan dalam penelitian ini.

Hasil penelitiandengan uji parsial diketahui besar pengaruh setiap variabel terhadap kejadian bendungan ASI berdasarkan nilai $\operatorname{Exp}(B)$ yaitu 1) Variabel frekuensi menyusui dengan nilai $\operatorname{Exp(B)~sebesar~42,094,~}$ berarti jika frekuensi menyusui semakin baik maka perkiraan kemungkinan tidak mengalami kejadian bendungan ASI sebesar 42 kali lebih besar dan 2) Variabel posisi menyusui dengan nilai $\operatorname{Exp}(\mathrm{B})$ sebesar 18,555, berarti jika frekuensi menyusui semakin baik maka perkiraan kemungkinan tidak mengalami kejadian bendungan ASI sebesar 18 kali lebih besar.

Menurut asumsi peneliti bahwa faktor yang paling mempengaruhi terjadinya bendungan ASI adalah frekuensi menyusui, dan posisi menyusui. Dengan keluarnya ASIyang lancar, maka responden tidak perlu repot untuk mengeluarkan banyak biaya, apalagi jika dilihat daripendapatan keluargasebagianbesar responden adalah menengah ke bawah, dengan pemberian ASI secara rutin maka pengeluaran keluarga dapat berkurang. Selain itu dari sebagian kecil responden, solusi apabila ibu bekerja, bayi diasuh selain ibu seperti saudara atau nenek, sebelum berangkat kerja bayi disusui terlebih dahulu.Dan pada saat ibu bekerja diberikan susu formula sebagai pengganti ASI sementara. Setelah ibu pulang bekerja, bayi tetap diberikan ASI kembali.Hal 
ini juga tidak mempengaruhi kelancaran ASI apabila tetap diimbangi dengan mengkonsumsi

\section{SIMPULAN (12pt)}

Kesimpulan dalam penelitian ini adalah Ada pengaruh frekuensi menyusui dengan nilai $p=0,000<0,05$, kondisi puting dengan nilai $p=$ $0,007<0,05$, perlekatan payudara dengan nilai $p=0,003<0,05$, posisi menyusui dengan nilai $p=$ $0,007<0,05$, perawatan payudara dengan nilai $p=0,005<0,05$ dengan bendungan ASI di Wilayah Kerja Puskesmas Rambung Merah Kabupaten Simalungun Tahun 2018 dan hasil analisis multivariat dengan menyatakan faktor yang paling dominan memengaruhi kejadian bendungan ASI adalah variabel frekuensi menyusui dengan nilai sig $p=0,000<0,05$ dan nilai $B$ atau logaritma natural terbesar yaitu 3,740 .

\section{UCAPAN TERIMA KASIH}

Terimakasih peneliti ucapkan kepada Kepala serta Staff Puskesmas Rambung Merah Kabupaten Simalungun yang telah membantu dalam melakukan penelitian ini.

\section{DAFTAR RUJUKAN}

1. Roesli U. Inisiasi Menyusu Dini Plus ASI Eklusif (Cetakan I). Jakarta: Pustaka Bunda. 2013;

2. Nugraheny E, Sulistyawati A. Asuhan Kebidanan Pada Ibu Bersalin. Salemba Med Jakarta. 2014;

3. Organization WH, Unicef. Trends in maternal mortality: 1990-2015: estimates from WHO, UNICEF, UNFPA, World Bank Group and the United Nations Population Division. World Health Organization; 2015;

4. Indonesia KK. Profil kesehatan Indonesia tahun 2015. 2015;

5. Dinkes Provinsi DIY. Survey Demografi dan Kesehatan Indonesia (SDKI). Jakarta: Depkes RI; 2012.

6. Manuaba IBG. Ilmu Kebidanan, Penyakit Kandungan \& Keluarga Berencana. In EGC; 2014.

7. Rukiah AY, Yulianti L. Asuhan Kebidanan Kehamilan Berdasarkan kurikulum Berbasis Kompetensi. Jakarta: Trans Info Media; 2014. makan makanan yang sehat.

8. Ardyan RN. Hubungan Frekuensi dan Durasi Pemberian ASI dengan Kejadian Bendungan ASIpada Ibu Nifas. KTI D3 KEBIDANAN. 2014;

9. Dewi VNL, Sunarsih T. Asuhan kebidanan pada ibu nifas. Jakarta Salemba Med. 2011;

10. Halina T. HUbungan Pengetahuan Menyusui dengan Teknik Menyusui yang Benar pada Ibu Primipara di Wilayah Desa Candi Kecamatan Bandungan Kabupaten Semarang. 2015;

11. Anggareni S. Faktor-Faktor yang Berhubungan dengan terjadinya Pembengkakan Payudara pada Ibu Postpartum di Rumah Sakit Pondok Indah. J Kesehat Masy. 2016;6(5):696703.

12. Yuliana I, Husada STIKK. Tingkat Pengetahuan Ibu Menyusui tentang Perawatan Payudara di BPS Aryanti Gemolong Sragen Tahun 2012. 2012;

13. Nurani A. 7 Jurus Sukses Menyusui. Elex Media Komputindo; 2013.

14. Notoadmodjo S. Metodologi Penelitian [Internet]. Jakarta: Rineka Cipta; 2013. Available from: https://ebekunt.files.wordpress.com/200 9/04/metodologi-penelitian.pdf

15. IP M. Hubungan Frekuensi Menyusui dengan Kejadian Bendungan ASI pada hari ke 1-7 Masa Nifas di RB Syifa Husada. Hub Frekuensi Menyusui dengan Kejadian Bendungan ASI pada hari ke 1-7 Masa Nifas di RB Syifa Husada. 2014;

16. Cadwell K, Turner-Maffei C. Buku saku manajemen laktasi. Jakarta EGC. 2011; 